\title{
Of International Law, Semi-colonial Thailand, and Imperial Ghosts
}

\author{
Prabhakar SINGH* \\ Jindal Global Law School, India \\ prabhakarsingh.adv@gmail.com
}

\begin{abstract}
I argue that contextually reading two disputes involving Siam-Cheek $v$. Siam (I 898) and the Temple of Preah Vihear (I962) - proves that both private law and public international law are structurally rigged against ex-semi-colonial nations. Nineteenth-century Siam was a political ferment known variously as a semi-colonial, semi-peripheral, non-colonial, or uncolonized polity. Siam bargained under imperial shadows its political independence by the tactical grants of concession contracts, as well as by negotiating treaties with competing European powers. In the post-colonial Temple of Preab Vihear case, colonial stationery-maps, photographs, and communiqués-as well as imperial customs offered evidentiary support to Cambodia, an ex-colonial state, against Thailand. In the early twentieth century, while authors picked Cheek $v$. Siam as a precedent for the law of international claims, textbooks offer the Temple of Preah Vihear case as a precedent on the form of treaties and estoppel. Conclusively, these two cases allow us to locate, if not exorcise, the ghosts of empires in Asian legal history, exposing, at the same time, Judge Koo's Orientalization of customary international law.
\end{abstract}

I focus on the distinction between colonialism and semi-colonialism, the two simultaneous political experiences of Asian societies, in this paper. As a framework of study, I evaluate the role of semi-colonialism in the universalization of international law in Indochina. Let us begin with what Gustave Rolin-Jaequemyns, General Advisor to Siam between 1892 and 1902, had to say about the state of negotiations and international law in Siam. 
Prince Devawongse is not always as firm as he is intelligent, and it happens sometimes to him that he lets go of points, in conversation in which I do not participate, which I had made in my messages. This also applies to the fact that he does not always exactly understand the value of words. Naturally the French gain advantage from this, and even exaggerate the importance of what he has said or admitted, and then discreetly congratulate him for what they call an act of emancipation from my tutorship. ${ }^{\mathrm{X}}$

No less than the Khedive of Egypt and the King of Siam coveted Gustave Rolin-Jaequemyns - a Belgian lawyer and the founding Secretary General of the Institut de droit international-to join them. Rolin-Jaequemyns's meeting with Prince Damrong in the winter of I89 I settled the matter in favour of Siam. He resigned from his position as Egypt's Attorney-General to sail for Siam. Rolin-Jaequemyns's decision had disappointed T.M.C. Asser and John Westlake, his two closest friends. Life turned full circle only seven years later. On Rolin-Jaequemyns's suggestion King Chulalongkorn almost appointed T.M.C. Asser, F.F. Martens, and J. B. Moore, arguably the three leading international lawyers of the late nineteenth century, as advisors and arbitrators for the interpretation of the Franco-Siamese Treaty of 1867 should France agree to arbitration. ${ }^{2}$ France chose gunboat negotiations over arbitration lest Siam found a more favourable legal award. Need anyone stress more the pivotal role Rolin-Jaequemyns played in Siam's tryst with international law?

However, more historians than international lawyers have studied Thailand. Siam, as Thailand was known during its admission to the United Nations, was never formally colonized. ${ }^{3}$ Should the lawyer's study of Siam yield a useful lens about it, to wit, semicolonialism, history, and international law? Notably in Asia, Japan, Siam, and China share a common semi-colonial past of varying degrees. ${ }^{4}$ Siam managed to remain independent at a time when the British and the French Empires had conquered Burma and Cambodia to, respectively, its west and east. ${ }^{5}$

I. "Letter of Gustave Rolin-Jaequemyns to his Son, 27 June I894" in Walter TIPS, Gustave RolinJaequemyns and the Making of Modern Siam (Bangkok: White Lotus, 1996), 74.

2. "Letter of Rolin-Jaequemyns to King Chulalongkorn", i I November I 898, ibid., at I 37 .

3. Sompong SUCHARITKUL, "Asian Perspectives of the Evolution of International Law: Thailand's Experience at the Threshold of the Third Millennium" (2002) I Chinese Journal of International Law 527. Stefan HELL, Siam and the League of Nations: Modernisation, Sovereignty and Multilateral Diplomacy, 1920-1940 (Bangkok: River Books, 2010) notes: some “acknowledge Siam's League membership in passing, but do not elaborate on what this membership meant". Sucharitkul's rich text on Thailand captures five centuries of Siamese experience with international law, albeit without mentioning the Case Concerning the Temple of Preah Vihear (Cambodia v. Thailand), Merits, [1962] I.C.J. Rep. 6. Sucharitkul says that "Thai" is a name older than Siam.

4. Admission of Siam to Membership in the United Nations, UNGA Resolution A/RES/IOI(I), UN Doc A/ 264, 67th Plenary Meeting (I 5 December 1946) I 458.

5. Edward GALLAUDET, A Manual of International Law (New York: S. Barnes \& Co., I879) I 59. "[S]o small a power as Siam". Memorandum of Consul E.H. French of the British Legation, Bangkok, 9 November I893, F.O. I7/I 86, para. 2. Lassa OPPENHEIM, International Law: A Treatise, vol. I: Peace (Bombay: Longmans, Green, \& Co., I905) 33, I48: Siam is a "doubtful" state. Smith called Siam a "Partially civilized state". Frederick SMITH, International Law, 5 th ed. (London/Toronto: Dent \& Sons, I9I8) 8I. For Westlake, "Siam and China" were examples of states where "the international society exercises the right of admitting states to parts of its law without admitting them to the whole of it". John WESTLAKE, International Law, Part I: Peace (Cambridge: Cambridge University Press, I9I0) 40. Edwin DEWITT DICKINSON, Equality of States in International Law (London: Harvard University Press, I920) 355: Siam is a "Secondary power". After all, "[r]ecognition is never immediately 
In the twentieth century, while South Asia was under British "colonial rule", Thailand and China were under the "foreign domination" of Japan and the European powers. ${ }^{6}$ Siam's tryst with international law in the nineteenth century-its attempt to join the "civilized" family of nations-is, arguably, unique in Asia. ${ }^{7}$ It is so because, their common history notwithstanding, Japan, China, and Siam were to chart completely different futures during, respectively, the interwar and the postwar years. ${ }^{8}$

Its independence notwithstanding, how did Western lawyers treat Siam? Oppenheim-perhaps the most influential of the writers of the twentieth century-had conflated the two political situations-colonial rule and semi-colonialism-to hold Siam as a "doubtful" case insofar as its recognition and admission into the family of nations was concerned. 9 The American Journal of International Law had at the time noted: "Oriental nations, however old their civilization, are not by the mere fact of statehood regarded as equals." то To Western lawyers, problematically, semi-colonial Siam and colonial India were states of the same ilk. Ironically, a veritable absence of a Machiavellian attitude excluded such oriental states from the reckoning for statehood. ${ }^{\text {II }}$ As the daughter of Prince Damrong noted: "It was generally known at the time that we only

forthcoming, Hegel repeated, and if a collection of people is to gain it, they must first fight for it”. Erik RINGMAR, "The Relevance of International Law: A Hegelian Interpretation of a Peculiar SeventeenthCentury Preoccupation" (I995) 2I Review of International Studies 87 at 96.

6. In its written submission to the ICJ in the Kosovo case, the People's Republic of China made reference to "colonial rule and foreign domination". "Written Statement of China to the International Court of Justice on the Kosovo Issue" (2009) 3, online: ICJ < http://www.icj-cij.org/files/case-related/I4I/I 5 6I I. pdf $>$. Judge Xue, China's ambassador to the Netherlands a year before the Kosovo affair, is putative author of the letter to the ICJ. XUE Hanquin, "Cultural Element in International Law", Melland Schill Lecture, University of Manchester (5 May 2016) at 5, spoke of "colonial rule and foreign domination" verbatim again.

7. " $[\mathrm{I}] \mathrm{n}$ the far East, the French and the English consolidated their position and advanced towards each other to meet at a point which was called Siam." Baron Edouard ROLIN-JAEQUEMYNS, Foreword, in Tips, supra note I at xi.

8. While Japan went for "defensive modernization", geopolitics compelled the Siamese state to pursue a strategy of "defensive underdevelopment". Tomas LARSSON, "Western Imperialism and Defensive Underdevelopment of Property Rights Institutions in Siam” (2008) 8 Journal of East Asia Studies I.

9. Oppenheim, supra note 5 at I 57, saying: "Siam, and Tibet are for some parts only within that family [of Nations]." Kingsbury has defended and appraised Oppenheim's textbook in two seminal papers. Benedict KINGSBURY, “Sovereignty and Inequality” (I998) 9 European Journal of International Law 599; Benedict KINGSBURY, "Legal Positivism as Normative Politics: International Society, Balance of Power and Lassa Oppenheim's Positive International Law" (2002) I3 European Journal of International Law 401 .

Io. Editorial, "British Extraterritorial Jurisdiction in Siam" (I909) 3 American Journal of International Law 954. Richard HOROWITZ, "International Law and State Transformation in China, Siam, and the Ottoman Empire During the Nineteenth Century" (2004) I 5 Journal of World History 445, noted the universalization of international law as a "joint enterprise": "The integral part played by extra-European events, actors, or practices needs to be incorporated into our understanding of modern state formation." Jordan BRANCH, "'Colonial Reflection' and Territoriality: The Peripheral Origins of Sovereign Statehood” (2010) I 8 European Journal of International Relations 277 at 280.

I I. In the twentieth century, while the Montevideo Convention lists the four essential characteristics for a state, there are no international laws on state recognition but only two competing theories: constitutive and declaratory. See art. I, Montevideo Convention on the Rights and Duties of States (I933) I65 L.N.T. S. I9 (entered into force 26 December 1934). Naturally, the subject of state recognition has had an ample purchase with publicists. See the two leading texts: Hersch LAUTERPACHT, Recognition in International Law (Cambridge: Cambridge University Press, 1947), and James CRAWFORD, The Creation of States in International Law (Oxford: Clarendon Press, I979). Benedict KINGSBURY, "Whose International Law? Sovereignty and Non-State Groups" (I994) 88 ASIL Proceedings I. 
give the French an excuse to seize more territory by protesting. Things had been like that since they came into the river Chao Phya with their gunboats." ${ }^{\text {2 }}$ Effectively, the Western imperial machinations, Empires, and their scholars, held Siam down by unequal treaties even as it shut, with the other hand, the doors of the family of civilized nations on it.

What is semi-colonialism, however? A metropolitan country in semi-colonialism exerts power and influence within an asymmetrical relationship without assuming "outright domination and formal sovereignty over the peripheral country", as in colonialism. ${ }^{\mathrm{I} 3}$ "Foreign domination" and semi-colonialism are interchangeable political experiences in East Asia and Indochina, which can be contrasted with British colonialism in South Asia. ${ }^{\mathrm{I}}$

The political sociologists Vandergeest and Lee Peluso have noted the Thai semicolonial situation: the Bangkok monarchy avoided the legal fragmentation-separate legal codes for different categories of people-that was prevalent in fully colonized polities. ${ }^{15}$ Nevertheless, extra-territoriality, or the exemption of European and American subjects from Siamese laws as specified in the mid-nineteenth-century treaties, might be "considered a limited form of such fragmentation". ${ }^{16}$ The primary motivation for Siam to change its legal system was to meet European conditions for ending legal extra-territoriality. ${ }^{17}$ Regardless, enormous gaps between the law and practice remained. ${ }^{\text {I } 8}$

That said, China takes the lion's share of attention among the works on semicolonialism and informal empires in Asia. ${ }^{\text {I9 }}$ Siam's case is largely understudied.

I2. Dissent of Wellington Koo, in the Temple of Preah Vihear case, supra note 3 at 9I, para. 34.

I3. Jürgen OSTERHAMMEL, "Semi-Colonialism and Informal Empire in Twentieth-Century China: Towards a Framework of Analysis" in Wolfgang MOMMSEN and Jürgen OSTERHAMMEL, eds., Imperialism and After: Continuities and Discontinuities (London: Allen Lane, I986), 290 at 308.

I4. Indochinese "states derive their civilisation from India but fall within the political orbit of China". John Sydenham FURNIVALL, "The Tropical Far East And World History" (I952) 39 Journal of the Siam Society II 9 at I 20.

I 5. Peter VANDERGEEST and Nancy LEE PELUSO, "Territorialization and State Power in Thailand" (I995) 24 Theory and Society 423.

I6. Ibid.

I7. Ibid. In the nineteenth century "civilized nations" meant the legal system of a nation provides protectioneconomic and physical- to aliens and citizens alike. For Asian polities, having such a system became imperative for political independence. Thus, for Siam, internal legal reform became the basis for the revision of unequal treaties. Tokichi MASAO, “The New Penal Code of Siam” (1908) 18 Yale Law Journal 85. "[I]t is not to be denied that the existence of a legal system is a primal condition of statehood." Ivan SHEARER, Starke's International Law, I Ith ed. (New Delhi: Oxford University Press, I994) 86.

I8. Ibid., 424. A comparison between the Phra Yot (France/Siam) dispute and the Savarkar (France/Great Britain) instructively reveals the distinctions the Europeans made between intra-European and EuropeanAsian relations. In the Arrest and Return of Savarkar case, Award (24 February 1911), 4, online: PCA < https://pca-cpa.org/en/cases/79.pdf >, a Permanent Court of Arbitration tribunal found France's "defective extradition" not in violation of international law. In contrast, Phra Yot was tried twice to be awarded a death sentence.

19. For example, even Sucharitkul's seminal paper on Thailand notes that "the Celestial Empire, China, suffered the most painful and the least tolerable fate with the most indelible injurious consequences". Sucharitkul, supra note 3 at 533. "Semi-colonialism", "foreign domination", and "joint-enterprise" are some of the words used to describe the political situation of China, Ethiopia, and Siam in the interwar years that post-colonial lawyers conflated with colonialism. While Asia is often inaccurately presented as a homogeneously colonized continent, the distinction between the nature of the Japanese and European semi-colonialism is the new area of study pioneered by historian Prasenjit DUARA, Sovereignty 
Clearly, the abundance of modern nation-states of Westphalian persuasion and its wilful universalization pushes into insignificance the semi-colonial nations like Siam's lived experiences. One would expect the alternatively modern lived experiences of such Asian polities-flexible and hybrid-to bear upon the rigid statist conceptions of the modern international law. ${ }^{20}$

Obviously, Asian polities under "foreign domination" were less legalistic in comparison to those under direct "colonial rule". ${ }^{2 \text { I }}$ Naturally, the former produced lesser stationery than the latter. If anything, the production, cataloguing, and archiving of the colonial stationery was, in fact, an essential part of running the colony. Contrarily, Siam, a semi-colonial polity, would borrow in good faith from the French and the British such colonial stationery as maps. ${ }^{22}$ Furthermore, the unequal treaties imposed on Siam foisted limitations as well as European scrutiny on Siam's hiring of experts. For example, by Article 6 of the Franco-Siamese Treaty 1904, the French forced Siam to deploy only "troops of Siamese nationality, commanded by officers of the same nationality". ${ }^{23}$ Prior "understanding" with the "French Government" had to be "reached" "should the Siamese Government wish to replace these officers with foreign officers of another nationality". ${ }^{24}$ Article 6 forced Siam to recruit the "police contingent" exclusively from "the natives of the locality". ${ }^{25}$

In the middle of the nineteenth century, the terms of the Bowring Treaty of $185 \mathrm{I}$ had constrained the policy options available to the Siamese state, particularly in its efforts to respond to external threats. Strengthening its authority and control over territory and population continued to remain a challenge. At the time, John Westlake-worried

and Authenticity: Manchukuo and the East Asian Modern (Lanham: Rowman \& Littlefield, 2003) 9I. Judge Koo found the League's failure to prevent Japanese imperialism in China pivotal to the League's death. Stephen CRAFT, "Saving the League: V.K. Wellington Koo, the League of Nations and SinoJapanese Conflict, I93 I-39” (2000) I I Diplomacy \& Statecraft 9I. Subsequently Ethiopia's semicolonial situation caught the attention of scholars. Jean ALLAIN, "Slavery and the League of Nations: Ethiopia as a Civilized Nation" (2006) 8 Journal of the History of International Law 2I3 at 22 I. Andrew FITZMAURICE, "Liberalism and Empire in Nineteenth-Century International Law" (20I2) I 7 American Historical Review I 22 at I3I. The study of Japan, China, and Ethiopia, although to the exclusion of Siam, has inspired a general study of interwar years. Natasha WHEATLEY, "Spectral Legal Personality in Interwar International Law: On New Ways of Not Being a State” (2017) 35 Law \& History Review 753 .

20. In cases involving Asian states, the ICJ has "avoided assessing the quality of territorial control by states, which is at the heart of the difficulties of the law of territory in the post-colonial era". Sookyeon HUH, "Title to Territory in the Post-Colonial Era: Original Title and Terra Nullius in the ICJ Judgments on Cases Concerning Ligitan/Sipadan (2002) and Pedra Branca (2008)" (2015) 26 European Journal of International Law 709 at 7I2. But the frontiers of states "need not be established beyond dispute". Malcolm SHAW, "Territory in International Law" (I982) I 3 Netherlands Yearbook of International Law 6r. "[T]erritory requirement ... is not necessarily essential to the continued existence of an established state." Abhimanyu GEORGE JAIN, “The 2 Ist Century Atlantis: The International Law of Statehood and Climate Change-Induced Loss of Territory" (20I4) 50 Stanford Journal of International Law I at $5 \mathrm{I}$.

2I. Xue, supra note 6 at 5 .

22. "The weight of documentation does not necessarily correspond to the weight of the arguments." Mohammed BEDJAOUI, “The 'Manufacture' of Judgments at the International Court of Justice” (I99I) 3 Pace Yearbook of International Law 29 at 37.

23. Franco-Siamese Treaty I904, art. 6, para. 2.

24. Ibid.

25. Ibid., para. 3 . 
about the French "Wolf and Lamb" treatment of "Further India"-felt "sorry to see the variety of types of civilization, already becoming too scanty, further diminish". ${ }^{26}$

I argue that colonialism is, generally speaking, a phenomenon of advantage to countries formerly under colonial rule in relation to interstate disputes on territory and boundary. Conversely, countries that battled semi-colonialism stand in a position of permanent disadvantage in interstate third-party adjudication. This is so because countries under colonial rule could use the archives and expertise of the erstwhile colonial powers. ${ }^{27}$ Indeed, as Crawford and Miles note, "unreliable record-keeping, non-maintenance or destruction of archives and linguistic barriers have prevented other voices from being heard". ${ }^{28}$ Much less still, nations such as Siam under "foreign domination" are found wanting in producing actual evidence such as maps. ${ }^{29}$

More generally, I ask how the varied colonial and semi-colonial pasts of Asian nations might play out in territorial disputes between such nations before international courts. I study two cases involving Siam - Cheek $v$. Siam (I 897) arbitration, ${ }^{3 \circ}$ and the Temple of Preah Vihear (1962) ${ }^{3 \mathrm{I}}$ dispute between Cambodia and Thailand-to answer that question. Cheek v. Siam is a key precedent to understand Siam's attempt to maintain its independence from French colonial expansion. The Temple of Preah Vihear case, I argue, exposes the ways in which semi-colonial states stand at a disadvantage in relation to states that are a product of full-blown colonialism. Consequently, I emphasize the international lawyer's scrutiny of the presence of the Empires as ghosts in actual territorial disputes between such states. Overall, I argue that these two cases should be read in their historical context beyond the well-known textbook approach.

The following argumentative structure would be necessary to establish my aforementioned thesis. Part I establishes semi-colonialism as a framework to study Siam by

26. Letter of John Westlake to Rolin-Jaequemyns, 20 January I 893, in Tips, supra note I at 23.

27. This explains the dominance of men, mostly white, from France and England-two countries that colonized most of the world-in litigations before international courts and tribunals. There is now a shift to Americans, albeit men again, with the arrival of law firms. Yves DEZALAY and Bryant GARTH, Dealing in Virtue: International Commercial Arbitration and the Construction of a Transnational Legal Order (Chicago: Chicago University Press, I996) 63. The Reinterpretation of Preah Vihear litigation was televised in Thailand. Request for Interpretation of the Judgment of I June 1962 in the Case Concerning the Temple of Preah Vihear (Cambodia v. Thailand) Judgment, [20I3] I.C.J. Rep 28I. To Counsel Alain Pellet, the Thai people appreciated the lengths to which the Thai government had gone to make a case for the Temple ownership, and Thai people on the street could recognize Professor Pellet. Email correspondence with Alain Pellet, Université Paris Nanterre, I 2 December 2017.

28. James CRAWFORD and Cameron MILES, "Four Ways of Thinking about the History of International Law", in Juan CARLOS SAINZ-BORGO, Helga GUĐMUNDSDÓTTIR, Guðrún D. GUĐMUNDSDÓTTIR, Juan M. AMAYA-CASTRO, Mihir KANADE, Yara SAAB, and Humphrey SIPALLA, eds. Liber Amicorum - In Honour of a Modern Renaissance Man His Excellency Guðmundur Eiríksson (Gurugram: LexisNexis, 2017) 288.

29. Maps are not determinative in all cases, however. See Land and Maritime Boundary Between Cameroon and Nigeria (Cameroon v. Nigeria: Equatorial Guinea intervening), Judgment, [2002] I.C.J. Rep 303. James THUO GATHII, "Geographical Hegelianism in Territorial Disputes Involving Non-European Land Relations: An Analysis of the Case Concerning Kasikili/Sedudu Island (Botswana/Namibia)" (2002) I 5 Leiden Journal of International Law 58I. See Need for Greater Use by the United Nations and its Organs of the International Court of Justice, GA Res. A/RES/I7I(II) A (I947), at I03-4.

30. Marion Cheek (US) v. Siam, I 898, Marjorie M. WHITEMAN, ed., Damages in International Law, Vol. 3 (Washington: US Government Printing Office, I943) I646.

3I. Temple of Preah Vihear case, supra note 3 at 6. 
comparing the methods that legal historians and lawyers employ. Part II records the making of unequal treaties in Indochina. This section also discusses the role of colonial corporations in territorial capture. Part III registers the politics of investor-state commercial arbitration and the application of private law in the Cheek $v$. Siam (I 898) arbitration. This section highlights Siam's political strategy of distributing contracts to competing colonial powers to ward off a potential colonial capture. Part IV moves to the twentieth century to offer a detailed account of the majority and minority judgments, including their reasoning, in the Temple of Preah Vihear (1962) litigation. Next, Part V discusses the juridical ambivalence of the early post-colonial jurists engaged in issues of territory, state, and people in Asia generally and the Temple of Preah Vihear cases in particular, before concluding in Part VI.

\section{OF HISTORIANS AND LAWYERS: A FORK IN THE POST-COLONIAL ROAD?}

In the immediate decades after the World War II, historians and lawyers deployed two theoretical lenses-post-structuralist and post-colonial-to read international law. ${ }^{32}$ This methodological dispute between post-structuralism on the one side, and postcolonialism on the other, continues to reflect in international legal scholarship today. The lived experiences of colonial subjugation remain the most identifiable difference between the two. Add to that the fact that international legal scholarship has often conflated Asia's colonial and semi-colonial experiences.

Bringing much needed nuance to Asian legal history, historian Prasenjit Durara theorizes that Japanese semi-colonialism is functionally different from European colonialism. Duara defines the Manchukuo enterprise between Japan and Republican China as the "first full-blown instance" of a "new imperialism". This imperialism was "new" insofar as it was "rooted in the historical circumstances of the United States, the Soviet Union and Japan, rather than in those of the older European powers". ${ }^{33}$ More importantly, this "new imperialism reflected a strategic conception of periphery as part of an organic formation designed to attain global supremacy for the imperial power". ${ }^{34}$

The imperialism that evolved [in] the twentieth century differed especially from earlier European ... colonial[ism] in several ways. While the new imperialists maintained ultimate control of their dependencies or clients through military subordination, they often created or maintained legally sovereign nation-states with political and economic structures that resembled their own. ${ }^{35}$

32. The proponents of "orthodox Marxist historiography" as well the adherents of a "continuity thesis" who "wish to paper over differences between precolonial and colonial political regimes and knowledge systems" today reject both post-colonial Said and post-structural Foucault. Sanjay SUBRAHMANYAM, Europe's India: Words, People, Empires: I 500-1800 (London: Harvard University Press, 2017) xii.

33. Prasenjit DUARA, “The New Imperialism and the Post-Colonial Developmental State: Manchukuo in Comparative Perspective” (2006) 4 Asia Pacific Journal I.

34. Ibid.

35. Ibid. 
Evidently, Japan was competing with European powers in state-making in Asia during the early decades of the twentieth century. Very significantly, Japan and the West took a diametrically opposite approach to imperialism in semi-colonies; while the former created a new nation-state, the latter brought old native kingdoms down. For example, Ernest Satow, British Minister at Bangkok in I 884, recommended a typical European formula: "If the Siamese, Laos and Burmese Shans were ultimately to be united under one sceptre, that would constitute a populous and homogeneous state." ${ }^{36}$ Such an artificial state, for Satow, "might perhaps become strong enough to maintain its independence without extraneous aid".37

As for Siam, Japan has played a special role in Siamese legal history. ${ }^{38}$ Tokyo was the first of the colonial powers to accept "a provisional clause in a treaty with Siam by which extraterritorial rights would disappear if and when internal reforms progressed to the point where the Siamese legal and juridical treatment could be on a par with the Western or 'civilized' nations". ${ }^{39}$ As a result, by the year I900, Dauge, Belgium's legal advisor, had already noted that: "Extraterritoriality has as its objective to assure to the nationals of certain States a protection which they believe they cannot obtain otherwise in a country less civilized than their own. This reason does not apply to subjects of States that find in Siam at least as much legal protection as in their homeland." 40 This was remarkable since, only six years before, John Westlake had called Siam "a semicivilized buffer state". ${ }^{4 \mathrm{I}}$

Therefore, in the post-World War II world nations emerging in Indochina were a product of both a long European colonialism and a short Japanese imperialism. How did the post-colonial international lawyers respond to this fork in the road? Faced with spawning imperialism as well as an attempt to diagnose the nature of post-colonialism, in I96I Syatauw attempted to decouple Asia's colonial and semi-colonial past. ${ }^{42}$ Syatauw, much like historian Duara today, had gainfully decoupled the Asian past as early as I96I to theorize that both erstwhile semi-colonial and colonial states did not after decolonization yield the same kind of "newly established Asian states". ${ }^{43}$ Likewise, in the first decade of the twenty-first century, post-colonial international legal scholarship has witnessed a rise of the publicists of two different theoretical

\footnotetext{
36. Confidential Letter of E. Satow to Lord Salisbury, 25 September I 885 , F.O. 69/ıoo.

37. Ibid.

38. Letter of Rolin-Jaequemyns to King Chulalongkorn, undated, in Tips, supra note I at 240.

39. Tips, Ibid., at $4 \mathrm{I}$.

40. August DAUGE, "De la condition juridique des étrangers et de l'organisation judiciaire au Siam" (I 900) 27 Journal de Droit International Privé 46I. Charles Cheney HYDE, “The Relinquishment of Extraterritorial Jurisdiction in Siam" (I92I) I 5 American Journal of International Law 428. Francis Bowes SAYRE, "The Passing of Extraterritoriality in Siam" (I928) 22 American Journal of International Law 70 at 79. Austen PARRISH, "Reclaiming International Law from Extraterritoriality" (2009) 93 Minnesota Law Review 8 I 5 at 820.

4I. Letter of Westlake to Rolin-Jaequemyns, Io August I 894, in Tips, supra note I at 67.

42. For Syatauw, Japan, China, and the Philippines, on the one hand, and India, Sri Lanka, and Burma, on the other, could not both be part of the same study called "some newly established Asian states" in postcolonial times. J.J.G. SYATAUW, Some Newly Established Asian States and the Development of International Law (Boston/ Leiden: Martinus Nijhoff, I96I) 3.

43. Ibid., at 3-4.
} 
persuasions: those who use colonialism as against those deploying a semi-colonial lens to amplify the postwar imperialism of international law.

Antony Anghie has famously established that colonial rule is central to the formation of international law in the nineteenth century. ${ }^{44}$ Matthew Craven, in contrast, thinks that semi-colonialism manifesting in the unequal treaty regime, and not colonial rule, is central to explaining the role of international law in Asia and the continuance of informal empires during the Cold War. ${ }^{45}$ To make Craven's point ontologically, for Becker Lorca, international law did not so much as impose itself on non-Western nations as the lawyers from semi-colonial states themselves appropriated international law to claim equality with European states. ${ }^{46}$

Small wonder, since Oppenheim had conflated colonial and semi-colonial Asian states at the height of positivism, Oppenheim's appropriation by post-colonial scholars ensured the inheritance of an international law that remains blind to the difference between, for instance, Siamese semi-colonial and South Asian colonial history.

It explains a good deal of what happened afterwards in post-colonial approaches to international law. Post-colonial lawyers spawned two kinds of post-colonial approaches to international law. While the semi-colonials went to the length of ossifying the individual history of their own nations in order to claim a place in the family of nations, the publicists of colonial states argued for an already existing native tradition of international law in their countries. ${ }^{47}$ Notably, Craven and Becker Lorca omit Sya-

44. "[F] the international lawyers, colonial problems constituted a distinct set of issues that were principally not of a theoretical, but rather a political character." Antony ANGHIE, "Finding the Peripheries: Sovereignty and Colonialism in Nineteenth-Century International Law" (I999) 40 Harvard International Law Journal 3. This narrative was further strengthened in Antony ANGHIE, Imperialism, Sovereignty and the Making of International Law (New York: Cambridge University Press, 2005) at 3, where Anghie makes a broad argument that "colonialism was central to the constitution of international law". Upendra BAXI, "New Approaches to the History of International Law" (2006) I9 Leiden Journal of International Law 555 .

45. "It was not, as Anghie and others readily accept, merely about subjugation or rule, but about subjugation for a purpose-whether that be to civilize or exploit (or both)." Matthew CRAVEN, "What Happened to Unequal Treaties? The Continuities of Informal Empire" (2005) 74 Nordic Journal of International Law 335 at 382 . While Anghie investigates how the story of colonization and international law is written, Craven is "concerned with examining the way in which the story of decolonisation has been and continues to be told". Matthew CRAVEN, The Decolonization of International Law: State Succession and the Law of Treaties (New York: Oxford University Press, 2007) I6.

46. Building upon Horowitz and Craven, Becker Lorca notes that "international law became universal through semi-peripheral appropriation". Arnulf BECKER LORCA, "Universal International Law: Nineteenth-Century Histories of Imposition and Appropriation" (20I0) 5I Harvard International Law Journal 475. See Lauren BENTON and Lisa FORD, Rage for Order: The British Empire and the Origins of International Law, 1800-1850 (London: Harvard University Press, 2016). Jennifer PITTS, Boundaries of the International: Law and Empire (London: Harvard University Press, 2018) at 164 seemingly walks the path opened by Becker Lorca and Benton and Ford.

47. For instance, Chinese and Indian scholars made different arguments about international law and its universality. Prabhakar SINGH, "Sino-Indian Attitudes to International Law: Of Nations, States and Colonial Hangovers" (2015) 3 Chinese Journal of Comparative Law 348. K. KRISHNA RAO, "The Preah Vihear Case and the Sino-Indian Boundary Question" (I962) 2 Indian Journal of International Law 356, had argued that the Temple of Preah Vihear case be seen as a binding precedent for the ChinaIndia boundary dispute. Given the common Thai and Chinese semi-colonial pasts, Thai scholar Sucharitkul is unsurprisingly also an expert on Chinese scholarship. See Sompong SUCHARITKUL, "Rebirth of Chinese Legal Scholarship, with Regard to International Law" (1990) 3 Leiden Journal of International Law 3. 
tauw's analytical framework. ${ }^{48}$ Quite tellingly, Syatauw had prefigured the problems associated with painting nineteenth-century Asian history in singularly colonial ink. Because Syatauw's analytical framework has since been lost on publicists, scholars of Asia and international law find inexplicable the East and South Asian ambivalence towards international law. Notably, a new twenty-first century division of international legal academic labour is witnessing a rising school of post-structuralists; they hide behind an esoteric vocabulary as if to evade the wrath of post-colonial states. This has left the job of challenging the state for the post-colonials alone to do.

\section{UNEQUAL TREATIES AND SEMI-COLONIAL SIAM}

\section{A. Siam's Internal Consolidation}

Between I85I and I9I0, Siam confronted three issues: (I) internal integration or Siamese colonialism; (2) external territorial losses; and (3) the survival of an independent Siam. ${ }^{49}$ In the nineteenth century, the modernization of states in Asia had a particular meaning. "Oriental nations" could be "admitted to full membership in the Family of Nations upon satisfactory evidence that the citizens or subjects of foreign states enjoy within their dominions the rights, privileges, and protection of law accorded in European and American communities". ${ }^{\circ}$

The unequal treaty with Japan became the template for the subsequent unequal treaties that Europe and Japan signed with China and Thailand. However, not all the unequal treaties were similarly worded, Siam had terms and clauses different from the Japanese treaties. As Larsson notes, "provisions in treaties imposed on Siam beginning in I 855 prevented a 'developmental' political equilibrium from emerging in a state whose geopolitical vulnerability increased dramatically from the I 870 . The 'unequal' treaties imposed on Japan by Western powers were not similarly constraining, thereby allowing for the emergence of a developmental political equilibrium." ${ }^{\mathrm{I}}$

48. Craven "examine[s] how it was that international lawyers understood decolonization" and "to what extent, 'newly independent States' could really assert themselves to be 'new'". Craven, supra note 45 at 4. When examined in relation to international law on state succession, O'Connell and Bedjaoui, two opposing protagonists from Australia and Algeria, could not have been more different in their views. "If thus, Bedjaoui set himself against an imperial tradition that he believed to be represented in the work of O'Connnell [sic], O'Connell set himself against the sort of pointless special pleading that happened in the work of Bedjaoui." Craven, supra note 45 at 84 . Absent from Craven's account is Syatauw's direct criticism of O'Connell. "However correct and reasonable O'Connell's point of view may be", wrote Syatauw, "as a starting point, it simply will not do to say that states are bound at all times by a given system of law without being able to modify it.” J.J.G. SYATAUW, “The Relationship Between the Newness of States and Their Practices of International Law" in Ram Prakash ANAND, ed., Asian States and the Development of Universal International Law (New Delhi/London: Vikas Publishing, I972), Io at I4.

49. David WYATT, Thailand: A Short History (New Haven, CT: Yale University Press, I984) I8I. James MCCARTHY, "Siam" ( ( 888 ) Io Proceedings of the Royal Geographical Society I I7.

50. Editorial, supra note Io at 954. Cf. "Finding new ways of thinking about ancient states and empires means moving beyond the extremes of 'statist' and 'non-statist' histories. It means recognizing the existence of 'autonomous spaces' within state structures." Upinder SINGH, Political Violence in Ancient India (London: Harvard University Press, 2017) I3.

5I. Larsson, supra note 8 at $3,8$. 
Meaning and interpretation of such treaties presented a set of non-European cultural-legal problems. During negotiations, Siamese princes and kings did not "always exactly understand the value of words" they spoke to the Europeans. ${ }^{52}$ Much as Rolin-Jaequemyns wanted the Thai prince to be Machiavellian in negotiations about territories with France, the Siamese Prince Devawongse "had been too polite and not strong enough in his denials". ${ }^{33}$ Of course, international law would not admit such contexts to treaty making as part of treaty interpretations. ${ }^{54}$ Irony is deepened when politeness, silence, and "oriental courtesy" would translate, as it did in the Temple of Preah Vihear case, into loss of territory in the twentieth-century international adjudication.

Be that as it may, Rolin-Jaequemyns conducted law reforms as well as Siam's foreign relations up until I902. ${ }^{55}$ Between I909 and I925, revising unequal treaties was the highest priority for which Siam now employed American lawyers. ${ }^{56}$ As a result, much like Japan, Siam under Chulalongkorn had begun to learn colonial ways for territorial consolidation where, as Winichakul notes, “a new kind of geography in which neither overlapping margin nor multiple sovereignty was permitted". ${ }^{57}$ Although in the process of slow modernization, Siam had not abandoned its pre-colonial epistemology of statecraft. Maps continued to represent polity and not the exact territory, leading to confrontations "between different realms of geographical knowledge"..$^{8}$

Consequently, we may not expect modern Siam or France to conduct themselves in a "casual and inconsequential" manner in relation to territorial sovereignty, although Siam still saw itself as an unbounded kingdom working gradually to revise unequal treaties. As the closest minister to King Chulalongkorn, Prince Damrong supervised administrative and legal reforms in modern Siam. However, after the death of Chulalongkorn, as Judge Koo noted, Prince Damrong gave up his ministry to take up "duties connected with the National Library and archaeology". 59 Damrong's visit to the Temple, the visit that the International Court of Justice [ICJ] held

\footnotetext{
52. Rolin-Jaequemyns's Diary Entry, 22 August I 894, in Tips, supra note I at 74.

53. Ibid., at 79 .

54. "[D]uress, so far as States are concerned, does not invalidate a contract; nevertheless, it is submitted that this exception does not affect ... the fundamental identity of contract as treaties." Hersch LAUTERPACHT, Private Law Sources and Analogies of International Law: With Special Reference to International Arbitration (Bombay: Longmans, Green \& Co., I927) I6I.

55. Thamsook NURNNONDA, "The First American Advisers in Thai History" (I974) 62 Journal of the Siam Society I 2 I at I 24. The task was in essence to craft a new and modern Civil and Commercial Code, replacing a number of existing legal and judicial practices. Walter TIPS, trans. \& intro., Mr. and Mrs. Jottrand, In Siam: The Diary of a Legal Adviser of King Chulalongkorn's Government (Bangkok: White Lotus, I996 [1905]) vii. Christian DE SAINT-HUBERT, "Rolin-Jaequemyns (Chao Phya Aphay Raja) and the Belgian Legal Advisors in Siam at the Turn of the Century" (I965) 53 Journal of the Siam Society I $8 \mathrm{I}$ at $\mathrm{I} 87$.

56. Peter OBLAS, "Treaty Revision and the Role of the American Foreign Affairs Adviser I909-I925" (I972) 60 Journal of the Siam Society I7I.

57. Thongchai WINICHAKUL, Siam Mapped: A History of the Geo-body of a Nation (Chiang Mai: Silkworm Books, I995) I06.

58. Ibid., at 107 .

59. $\quad$ Dissenting Opinion of Judge Koo, Temple of Preah Vihear case, supra note 3 at 90, para. 32.
} 
binding against Siam in the Temple of Preab Vihear case, was not in his capacity as the "Minister of Interior". That Prince Damrong is considered the first authentic historian of modern Siam should not be lost on international lawyers. ${ }^{60}$ Between I9I 3 and I932, Damrong had been "shifting his focus from administration to academia". ${ }^{6 I} \mathrm{He}$ was Siam's first writer to construct Siam's history using Burmese sources for objectivity and perspective. ${ }^{62}$

\section{B. Colonial Corporations Between Trojan Horses and Unicorns}

European companies were vectors of the colonization of various intensities in Asia. Such colonial companies were, to use the Privy Council's words, "frequently of an ambiguous character, and [...] it becomes extremely difficult to ascertain, whether any particular act is to be attributed to the exercise of the political power of a sovereign State, or to the functions of a company of merchants trading to the East Indies". ${ }^{63}$ Asia, as it were, inherited its ambivalence for international law from the colonial companies. ${ }^{64}$

The unequal treaties with Asian polities, Craven thinks, did not have colonial capture or imperial annexation as their "overt intention". ${ }^{65}$ Although the territory of China and Siam were ceded, or leased to Western powers, "the dominant political ethos in Western Europe in the middle of the I9th Century was largely opposed to the expansion of formal colonial possessions-embracing, in its stead, the ideal of free trade". These unequal treaties thus encapsulate the aim to eliminate the "historic impediments to trade such as local monopolies". ${ }^{66}$

The colonial companies were the Trojan horses of territorial capture-not unicorns of free trade, as many would have us believe. Should one pay close attention to the physical manifestation of the "ideal of free trade", a different reality emerges. The representation of colonialism as an innocent spillover from free market ideology emerges from the

6o. Prince Damrong RAJANUBHAB, Our Wars with the Burmese: Thai-Burmese Conflict I539-I767, U AUNG THEIN, trans., Chris BAKER, ed. (Bangkok: White Lotus, 200I [I9I7]) xv. Kennon BREAZEALE, "A Transition in Historical Writing: The Works of Prince Damrong Rachanuphap" (I97I) 59 Journal of the Siam Society 25.

6I. Rajanubhab, ibid., at x.

62. Ibid., at xxxv. Damrong does not escape Winichakul's scholarly scrutiny, however. Winichakul found that Damrong's “selective treatment of only the Thai-Burmese wars, and the name of the book itself, were a clever way to frame Thai history which heavily influenced people's knowledge and interpretation of the past". Quoted in, Baker, ibid., xiv.

63. Ex-Rajah of Coorg v. East India Company (I 860) 29 Beavan 300, 309. In the Nabob of Arcot case, the EIC argued for the power to "enter into federal conventions with the princes or people that are not Christians". The Nabob of Arcotv. The East India Company (I793) 29 E.R. 84 I (Court of Chancery). In John Doe, on the demise of Rajah Seebkristo \& Ors v. the EIC, (I 856 ) I 40 I 4 E.R. 445 (Privy Council) it was argued that "By the Hindoo law a verbal grant of real estate is good, if followed by possession by the grantee".

64. To the extent that studies on Asia and international law are carried out without a conversation with Syatauw, the conflation of Asian colonial and semi-colonial histories continues. Simon CHESTERMAN, “Asia's Ambivalence about International Law and Institutions: Past, Present and Futures" (20I6) 27 European Journal of International Law 945.

65. Craven, supra note 45 at 345 .

66. Ibid. 
international lawyers' historically thin arguments. ${ }^{67}$ Thant Myint-U—a historian and grandson of the third Secretary General of the UN-notes a particular account of the modus operandi of the London Chamber of Commerce:

$[T]$ he Burmese Council of State imposed a large fine of over a hundred thousand rupees on the Bombay Burmah Trading Corporation. A provincial governor had charged that the Scottish company, based in Rangoon, had been allegedly exporting timber from Upper Burma without paying the proper royalties. The governor had imposed a fine, the company had appealed, and Mandalay had now upheld the provincial decision ... The British commissioner in Rangoon suggested impartial arbitration. But the Court of Ava would not be moved, and the London Chamber of Commerce petitioned Lord Churchill either to annex Upper Burma or at least to establish a protectorate over the irksome kingdom. ${ }^{68}$

International law in Indochina thus established its legal validity by coercing native states with unequal treaties. Consequently, what matters to the states formerly under foreign domination as well as colonial rule today? Arguably, the fact of occupation and possession in territorial disputes and not the real intentions behind the unequal treaty for free trade ultimately matter as evidence in international disputes. As a concrete example, the Temple of Preah Vihear dispute demonstrates that it is either the evidence of colonial possession or the colonial cartography, as fact, that holds the key to the operationalization of the law before a tribunal. Moreover, the irony of the ideal of free trade is further deepened when scholars today attribute Burma's eventual loss of independence in 1885 to Britain to the Bombay-Burmah Trading Corporation, where the Corporation played a "central role". ${ }^{69}$

\section{THE LAW AND POLITICS OF THE CHEEK V. SIAM ARBITRATION (I 898)}

The Cheek v. Siam arbitration conducted at the end of the nineteenth century provides an opportunity for a contextual analysis of the competing colonial stakes in Indochina. Cheek $v$. Siam flags the Siamese approach to colonial aggression. ${ }^{70}$ It prods us to go beyond textbooks to offer a distributive analysis of the stakes, assumptions, and impacts of competing French and British colonialism in Indochina.

67. As historian Sunil Amrith explains: “The Indian shipping industry tumbled in the I 82os: pushed to the margins by the rise of steam technology, squeezed by political pressure from British shipbuilders to restrict entry to Indian ships." Sunil AMRITH, Crossing the Bay of Bengal (Cambridge, MA: Harvard University Press, 20I3) 8I.

68. Thant MYINT-U, The River of Lost Footsteps: A Personal History of Burma (London: Faber \& Faber, 2008) I 2.

69. Nigel BRAILEY, “The Scramble for Concessions in I 880s Siam” (I999) 33 Modern Asian Studies 5 I 3 at 5 I6.

70. Marion Cheek (US) v. Siam, supra note 30 at I646. "Arbitration in Siam” The Straits Times (27 December I897) 2. "4 Ist Session, A/CN.4/SER.A/I989/Add.I(Part I)" (I989) 2 Yearbook of International Law Commission 20, para. 70 . 
April 23, 1889, Dr. M. A. Cheek, a eitizen of the United States, residing in Siam, entered into the following agreement with Prince Warawan Nakorn, who represented the Government of Siam:

First. That His Royal Highness Prince Warawan Nakorn agrees to advance to Dr. M. A. Cheek the sum of 600,000 ticals to be used in the working of teak forests and the purchasing of teak wood.

Second. That Dr. M. A. Cheek shall, by the way of security, execute a bill of sale mortgage in favor of His Royal Highness Prince Warawan Nakorn on all teak wood now belonging to Dr. M. A. Cheek, according to a schedule accompanying this agreement, and on all teak wood which may be worked or purchased by him during the enrrency of this agreement; also on 76 elephants now belonging to Dr. Cheek and on all elephants which may be purchased by, or which may beconie the property of. Dr. M. A. Cheek during the currency of this agreement. Dr. Cheek shall pay to His Royal Highwess Prince Warawan Nakorn interest at the rate of 71 per cent per annnm on all moneys advanced to him by His Royal Highness Prince Warawan Nakorn.

Figure I Cheek borrows from Siam

Mr. Barrett to Mr. Olney.

No. 176.1

LEGATION OF THE UNITED STATRS,

Bangkok, Siam, March 2, 1897.

SIR: Acting on your telegraphed instructions of February 17, various suggestions were made as to the selection of the arbitrator. While the governor of the Straits Settlement might have been accepted, it was thonght best to secure a distinguished jurist, if possible.

I presented the name of Sir Nicholas J. Hannen, British ehief justice and consul-general at Shanghai. The foreign minister at once avcepted, and we agreed to address him a joint note asking him to serve. We hope to telegraph or write him within a few days.

In my opinion, if Sir Nicholas J. Hannen will consent to act, we will be assured of an able and impartial arbitrator. He ranks as one of the most capable jurists in the Far East, is an authority on extraterritoriality and international law, and has a thorough knowledge of Asiatics.

The foreign minister held that the arbitrator should sit in Siam. While I thought that this should be left to the arbitrator, I saw that objection to the wish would prolong discussion, and hence yielded. We will therefore suggest to the arbitrator that he sit here in November or December. Before that date climatic conditions would hardly warrant us in asking him to come to Siam. It also gives sufficient time to make full arrangements without undue haste.

I have the honor to await. any further instrnctions and trust that you will be good enough to forward them at your earliest couvenience. as it is my desire to have all details settled before going to Cheangma in June or July to investigate the Kellett matter.

I have the honor, etc.,

JOHN BARRETT, Minister Resident.

Figure 2 Hannen becomes the sole arbitrator

\section{A. The Cheek v. Siam Arbitration}

Dr Marion Cheek, an American national, operated a teak felling business in northern Siam. He ran out of capital in $\mathrm{I} 888$. The Siamese government encouraged the presence of competing colonial powers in the teak felling industry to dilute the monopoly of the British in the timber trade. The Siamese government had therefore "twice loaned Cheek sufficient capital for the continuation of his business". ${ }^{7 \mathrm{I}}$ However, when Cheek repeatedly defaulted on his interest payments between I 890 and I 892 , "the government moved to confiscate his leases". ${ }^{2}$

7I. Patrick TUCK, The French Wolf and the Siamese Lamb: The French Threat to Siamese Independence I858-I907 (Bangkok: White Lotus, I995) I 8I.

72. Ibid. 
As a result, the American Senate on 24 February I 897 passed a resolution in relation to the Cheek estate in Siam. ${ }^{73}$ Siam's confiscation of Dr Cheek's property triggered a diplomatic action. The American government decided to mount a legal claim on behalf of Dr Cheek. Under the principles of international law in the nineteenth century, governments could initiate arbitration on behalf of their nationals to recover their investments. Siam appeared to have violated the Treaty Between the United States of America and the Kingdom of Siam I 856. Part of the papers submitted to the Senate is shown in Figure I.

On I4 December I896, Mr Barrett, American Minister resident in Bangkok, first spoke of the Siamese government's desire to set up arbitration. The telegram show in Figure 2 suggests the name of the arbitrator, Sir Nicholas John Hannen, as the "one of the most capable jurists in the Far East". At the time, Sir Nicholas was serving as Chief Justice of Her Britannic Majesty in the Supreme Court of China and Japan in Shanghai. The Americans found Hannen sufficiently impartial and an expert in "extraterritoriality and international law" who also had a "thorough knowledge of Asiatics". ${ }^{4}$

In such ways, the Cheek $v$. Siam arbitration was set up. By an agreement on 6 July I 897 between Prince Devawongse and John Barrett, the parties agreed to refer every matter of the dispute, both facts and law, to arbitration. Cheek's case for ownership of the leases was upheld. On 2I March I898, Sir Nicholas Hannen wrote his award: "I am of opinion that such seizure and entry into possession was a violation of the second article of the treaty of 1856 between the United States of America and the Kingdom of Siam."75

The Cheek $v$. Siam arbitration turned into a dispute of the law of contract as a matter of applicable law. Siam justified the seizure of goods on the grounds of Dr Marion Cheek's "default in the performance of certain conditions of certain agreements made between him and the Siamese Government". ${ }^{76}$ One such condition, allegedly, was "the payment of interest upon a loan made by the Siamese Government to the said Dr. Marion A. Cheek upon the 3 Ist day of March of each year". ${ }^{77}$ Arbitrator Sir Nicholas Hannen noted:

Whereas it is necessary that before default in the performance of a condition can be proved, the existence of the condition in the contract must first be demonstrated, and Whereas I am of opinion that it was not proved to my satisfaction that the said contracts contained, or that their wording necessarily implied, in the minds of the parties such a condition as was alleged to have been broken ... I hereby award to the estate of the late Dr. Marion A. Cheek the sum of ticals 706,72I (seven hundred and six thousand seven hundred and twenty-one) as the indemnity to be paid by the Siamese Government for the satisfaction of all claims referred to my consideration. ${ }^{78}$

73. Grover CLEVELAND, "Arbitration of the Claim of M.A. Cheek against the Siamese Government" in Papers Relating to the Foreign Relations of the United States, with the Annual Message of the President Transmitted to Congress December 6, I897 (Washington: US Government Printing Office, I897) at 46I.

74. Ibid.

75. Cheek $v$. Siam Award in John BASSETT MOORE, History and Digest of the Arbitrations to Which the United States Have Been a Party (Washington: US Government Printing Office, , 898 ) Io68.

76. Ibid.

77. Ibid., at I069.

78. Ibid. 
Sir Nicholas thus spoke of absence in law and fact of both express and implied contracts and the lack of any "condition". Since there existed no condition of the kind Siam had imposed on Cheek, the question of its breach and therefore of the breach of the contract did not arise. ${ }^{79}$ Sir Nicholas ordered the estate of Dr Cheek to be "placed in the same position as it would have been in had not the Siamese Government seized the property" ${ }^{8 \circ}$ The Cheek case demystifies an age-old position on the separation of law and politics. Not only has public international law been political in unequal treaties, the purported relative normativity of the law of contracts exposes private law as a ghost in the imperial machinations.

\section{B. The Cheek v. Siam Arbitration and French Colonialism}

Cheek v. Siam is key to understanding how Siam, as an unbounded kingdom, sagaciously distributed to nationals of European states concessions that, far from representing a political threat, were expected to support and reinforce Siamese independence. Colonial powers had the technology of cartography upon which Siam heavily, even imprudently, relied. Siam, on the other hand, tactically distributed concession contracts to square off colonial threats.

The French came to know from the American Legation about the "availability for purchase of the Cheek concessions". ${ }^{8 \mathrm{I}}$ France had been trying to increase its influence in Siam in the second half of the nineteenth century without much success. ${ }^{82}$ At the time, Mr Defrance, a politician and diplomat, was tasked with the conduct of the French colonial project in Indochina. Siam could not legally cancel or prevent the French from acquiring the Cheek farm. In consultations with the Americans, the French proposed a French Syndicate to exploit the Cheek concessions. Defrance wrote to Paris beseeching the French government "to seize this opportunity for expanding French political influence". ${ }^{83}$ As with other industries, Defrance saw the benefits of undermining the British hold on the Siamese teak industry too. He hoped that once Siam was forced to recognize French rights to register some 20,000 protégé migrants from the Luang Prabang area of Indochina working Siamese teak forests in the north, "the French Syndicate would become a form of French political enclave".

Unfortunately for Defrance, the Banque de l'Indochine delayed its commitment for buying the Cheek concessions, and Defrance's political project collapsed. Notably, in the matter of commercial concessions, the Siamese were acutely aware of the political

79. "Only those promises which are supported by a legal consideration are legally binding." P.S. ATIYAH, An Introduction to the Law of Contract, 5 th ed. (Oxford: Clarendon Press, I995) I I 8. See Shivprasad SWAMINATHAN, "Eclipsed by Orthodoxy: The Vanishing Point of Consideration and the Forgotten Ingenuity of the Indian Contract Act I872" (20I7) I 2 Asian Journal of Comparative Law I4I.

80. Cheek $v$ Siam, supra note 75 at 1069. Notably, while Waner Sutton noted the Cheek $v$. Siam case in the very same year, the case found its way into J.B. Moore's History and Digest. W. SUTTON, "Cheek v. Siam" (г 899) 58 Albany Law Journal 53. By I9 15, the Cheek case appeared in Borchard's The Law of International Claims. E.M. BORCHARD, The Diplomatic Protection of Citizens Abroad: Or, the Law of International Claims (Cleveland: Banks Law Publishing Co., I925 [I9I 5]) 337.

8I. Tuck, supra note $7 \mathrm{I}$ at $\mathrm{I} 8 \mathrm{I}$.

82. Ibid., at I $8 \mathrm{I}$.

83. Ibid., at 182 . 
implications of allowing large foreign commercial enterprise of any kind, let alone those of the French, to develop in Siam. On the infrequent occasions, as Tuck writes, when the Siamese government was "prepared to sanction important concessions to Europeans, they usually gave them to nationals of states which, far from representing a political threat, might be expected to support and reinforce Siamese independence". ${ }^{4}$

Besides, awarding contracts to nationals of competing colonial powers ensured that the French would not attempt territorial capture in those areas. Under nineteenthcentury international law, such an attempt would give the government of the national with working contracts in Siam the right to diplomatically protect their national's economic interest. Thus, Siam used commercial contracts as an instrument against territorial capture. ${ }^{85}$

\section{THAILAND AND INTERNATIONAL LAW IN THE TWENTIETH CENTURY}

\section{A. The Temple of Preah Vihear case, I962: The Original Sin}

In 1959, Cambodia instituted proceedings against Thailand in the Temple of Preab Vihear case. In I962, by nine votes to three, the ICJ found that the Temple of Preah Vihear was situated in Cambodia. ${ }^{86}$ Evidently, the subject of the dispute was sovereignty over the region of the Temple of Preah Vihear. This temple stood on a promontory of the Dangrek mountain range, which constituted the boundary between Cambodia and Thailand. The dispute had its origins in the boundary settlements made in the period I904-I908 between France- then conducting the foreign relations of Indochina-and Siam. ${ }^{87}$

More particularly, the dispute involved the application of the Treaty of I 3 February I904. The Treaty, by virtue of a Franco-Siamese Mixed Commission, allegedly settled the frontier. The Commission was also expected to delimit the exact boundary. As per the Treaty of 1904, in the eastern sector of the Dangrek range, in which Preah Vihear was situated, the frontier was to follow the watershed line. ${ }^{88}$

In January-February 1907, the President of the French section reported to his government that the frontier line had been definitively established. The ICJ assumed that a frontier had been surveyed and fixed, although there was neither any record of any decision nor reference to the Dangrek region in any minutes of the meetings of the Commission. The ICJ took this view also because, at the time when the Commission might have met for the purpose of winding up its work, a further Franco-Siamese Boundary Treaty of 23 March 1907 was concluded. ${ }^{89}$

\footnotetext{
84. Ibid., at 183 .

85. Judge Guha Roy very poignantly noted: “To the extent to which the law of responsibility of states for injuries to aliens favours such [colonially acquired] rights and interests, it protects an unjustified status quo or, to put it more bluntly, makes itself a handmaid of power in the preservation of its spoils." S.N. GUHA ROY, "Is the Law of Responsibility of States for Injuries to Aliens a Part of Universal International Law?” (I96I) 55 American Journal of International Law 863 at 866.

86. Temple of Preah Vihear case, supra note 3 at 8.

87. Ibid., at I4-I5.

88. Ibid., at 17 .

89. Ibid., at I9-20.
} 
The preparation of maps constituted the final stage of the delimitation. Crucially, the Siamese government, lacking adequate technical means, had requested that French officers should map the frontier region. After the cartography, these maps were communicated to the Siamese government in I908. Amongst them was a map, the famous Annex I map, of the Dangrek range showing Preah Vihear on the Cambodian side. Cambodia principally relied on this map in support of its claim to sovereignty over the Temple.

Thailand, on the other hand, contested the Annex I map's validity. Thailand argued that the map had no binding character. It pointed out that the frontier indicated on the map was not the true watershed line according to the geography of the place. Consequently, Thailand made two arguments. First, for Thailand the true watershed line would place the Temple in Thailand; second, the map had never been accepted by Thailand. Alternatively, if Thailand had accepted the map, it had done so only because of a mistaken belief that the frontier indicated corresponded with the watershed line. ${ }^{90}$

The ICJ, however, did not agree with Thailand's arguments. It ruled that the map was communicated to the Siamese government as purporting to represent the outcome of the work of delimitation. Given Thailand's silence at the time, and even much later, Thailand was deemed to have acquiesced to the validity of the map in law. ${ }^{\text {I }}$ The map was, moreover, communicated to the Siamese members of the Mixed Commission. The Siamese Minister of Interior, Prince Damrong, even thanked the French Minister in Bangkok for the maps. Besides, the map was also shared with Siamese provincial governors. If the Siamese authorities accepted the Annex I map without investigation, the ICJ said, they could not now plead in law any error vitiating the reality of their consent. $^{9^{2}}$

The later negotiations for the I 925 and 1937 Franco-Siamese Treaties confirmed the existing frontiers. Subsequently, in 1947, before the Franco-Siamese Conciliation Commission in Washington, Thailand did not protest. The ICJ read this as Thailand accepting the frontier at Preah Vihear as it was drawn on the map, irrespective of its correspondence with the watershed line.

Thailand stated that-having been at all material times in possession of Preah Vihear-it had had no need to raise the matter. In fact, Thailand cited the acts of its administrative authorities on the ground as evidence that it had never accepted the Annex I line at Preah Vihear. The Court found it difficult to regard such "local acts" as overriding the consistent attitude of the "central authorities". The Court therefore felt bound to pronounce in favour of the frontier indicated on the Annex I map in the disputed area, and it became unnecessary to consider whether the line as mapped did in fact correspond to the true watershed line. The Court thus upheld the submissions of Cambodia concerning sovereignty over Preah Vihear. ${ }^{93}$

\footnotetext{
90. Ibid., at 24 .

9I. Ibid. See Richard GARDINER, Treaty Interpretation, 2nd ed. (Oxford: Oxford University Press, 20I 5 ) 264 .

92. Ibid., at 30 .

93. In the Temple of Preah Vihear case, Cambodia's independence from France notwithstanding, the ICJ did not address the issue of Cambodia's succession from France. Craven, supra note 45 at I82.
} 


\section{B. The Three Musketeers of the Preah Vihear Temple: Judges Quintana, Koo, and Spender}

Not all the judges agreed with the merits ruling, however. The three dissenting opinions to the merits ruling of 1962 show the possibility of an epistemological alternative. ${ }^{94}$ Not that the majority bench in Preah Vihear was incapable of appreciating oriental epistemology. However, what the ICJ was incapable of during the Cold War was a political conviction to rethink international law's epistemological bases. The Court was not willing enough to go beyond the colonial law, despite the prodding by Judges Koo and Quintana in their dissenting opinions.

\section{Judge V.K. Wellington Koo}

As the head of nationalist China's delegation to the League of Nations, Wellington Koo was a famous proponent of the clausula rebus sic stantibus in relation to unequal treaties. Koo had experienced Japanese imperialism in China first-hand during the interwar years. ${ }^{95}$ Judge Koo wrote that a "customary act of Oriental courtesy" and the then prevailing conditions in Siam—and, in fact, in other parts of Asia-did not have the meaning and significance sought to be inferred from it by the French and other European colonial powers. ${ }^{96}$ The hostile relations between Siam and French Indochina allowed Judge Koo to uphold as "natural and reasonable" Bangkok's explanation that Siamese actions must not always be seen with a European eye. ${ }^{97}$ Indeed, a situation not peculiar to Siam, generally speaking, it was "the common experience of most Asiatic States in their intercourse with the Occidental Powers during this period of colonial expansion". ${ }^{8}$

In the postwar world, the same Judge Koo was clearly well placed to appreciate Thailand's predicament. ${ }^{99}$ Judge Koo displayed an acute understanding of Siam's semi-colonialism to offer an "Oriental" view of international law. Given Koo's interwar Manchurian experiences while reporting to the League of Nations, his empathy for the Siamese situation in relation to French colonialism in Indochina made his powerfully reasoned dissent in the Temple of Preab Vihear case inevitable. ${ }^{\text {Io }}$ Conclusively, as a lawyer trained in America and an eminent Chinese diplomat, Koo was perhaps the most perceptive, informed, and empathetic of the judges on the merits bench. He could

94. "[T]he separate opinions, and even the dissenting opinions, appended to the Judgment are integral with it and cannot be detached from it." Bedjaoui, supra note 22 at 58.

95. Wellington KOO, "Letter from the Chinese Delegation to the Secretary-General of the League of Nations, 26 April I933" (I933) 5 League of Nations Official Journal 6. Earlier Koo had resisted the legalization at the Permanent Court of International Justice [PCIJ] of the Republic of China's unilateral revision of the unequal treaty with Belgium. Denunciation of the Treaty of 2 November I 865 Between China and Belgium [I927] PCIJ (Ser. A) No. 8, pp. 4, 5. Pasha L. HSIEH, "Wellington Koo, International Law and Modern China" (2016) 56 Indian Journal of International Law 307.

96. Koo, ibid.

97. Ibid., at 91.

98. Ibid.

99. In February 1928, Wellington Koo, the then Chinese Minister in Paris, "pledged to try and secure [even] Japan's support for Siam's candidature" to the League of Nations' Council membership. Hell, supra note 3 at 70 .

Ioo. Dissenting Opinion of Judge Koo, in Temple of Preah Vihear case, supra note 59 at 80. 
offer, as he did, simultaneously an equally powerful legal and a situational analysis of the facts and law in the case.

While during the interwar years Judge Koo was a leading proponent of rebus sic stantibus, on the bench of the ICJ Koo transformed into a proponent of "local customary law". Only two years before, in his separate opinion in the Right of Passage case between an erstwhile colonial power (Portugal) and an ex-colony (India), Koo had rooted for a "local custom" and Portugal's colonial rights of military passage. ${ }^{\text {IOI }}$ Effectively, Koo had sided with the Portuguese claims, although he qualified his opinion by subjecting the right of military passage to India's "control and regulation”. Having written separate opinion in the Right of Passage case, Koo dissented in the Temple of Preah Vihear case. Koo thus made a clear distinction between India's colonial and Siam's semi-colonial past. Judge Koo found unsustainable “in fact or law" Siam's “customary act of Oriental courtesy" as binding on an erstwhile semi-colonial state. ${ }^{\text {I02 }}$

Furthermore, Judge Koo doubted if the Annex I map had a treaty character. He noted that the frontier line marked on the Annex I map was neither approved nor even discussed by the Mixed Commission of Delimitation. Besides, the French and Siamese Presidents of the said Commission did not agree to this. After tabling these "indisputable facts", Judge Koo opined that "the map in question does not possess a treaty character as claimed by Cambodia and therefore, as such, obviously cannot be binding upon Thailand in regard to the issue of territorial sovereignty over the Temple of Preah


and their different interpretation by the Thai Prince Damrong in relation to the planting of a flag. Koo was responding to Cambodia's argument that the planting of the French flag during a visit of Prince Damrong of Bangkok to the temple area constituted acquiescence by the latter in favour of the French. ${ }^{\text {IO4 }}$

The display of his national flag by a foreign official, even by a private Occidental, was not an uncommon sight in an Asiatic country during that epoch; it may or may not have displeased the Prince. There was no clear cause for the Prince to make a protest at the time or to ask his Government to lodge one in Bangkok, though in the affidavit of one of his daughters who was with the Prince during this visit, it is stated that he privately considered the hoisting of the French flag at the place of their meeting and the donning of his official uniform by the French officer to be "impudent". ${ }^{\text {105 }}$

Next, as to Prince Damrong's request to the French for further copies of the alleged map, Judge Koo said it was not difficult to understand his request. Prince Damrong, given Siam at the time did not yet have a good modern map showing the whole frontier

\footnotetext{
IоI. Case Concerning Right of Passage over Indian Territory, (Merits), Separate Opinion of Judge VK Wellington Koo [I960] I.C.J. Rep. 6 at 54.

102. Dissenting Opinion of Judge Koo, supra note 59 at 75, 90 . A germ of such an idea existed in ancient Sinonomadic relations. "From the nomads' perspective, the presents to the Chinese could readily be regarded simply as routine acts of courtesy, rather than as a sign of subjection." Stephen NEFF, Justice Among Nations: A History of International Law (Cambridge, MA: Harvard University Press, 2014) 40.

I03. Koo, supra note 59 at 80.

I04. Colonial stationery, however, doesn't really capture the practice of planting flags. This is covered by the "oriental" practices and customs. Ibid.

I05. Dissenting Opinion of Judge Koo, supra note 59 at 90, para. 33.
} 
region between Siam and French Indochina, "called for more copies for distribution to the Siamese provincial authorities". ${ }^{106}$ It was part of a gradual learning in Siam where, as Winichakul would put it: "To fulfill the desire to have their geo-bodies concretized and their margins defined for exclusive sovereignty, the French and the Siamese alike had fought both with force and with maps." ${ }^{107}$ Because maps signified different priorities, a century of semi-colonial experience had forced Siam to learn colonial cartography, for which it was dependent upon Britain and France. Therefore, decades prior to the dispute Siam did not possess European cartographical capabilities. ${ }^{\text {I०8 }}$

Judge Koo gives context to the establishment of the Franco-Siamese Mixed Commission. Thailand's chief claim before the Commission consisted of retrocession from France of several entire provinces. Siam had yielded territories to France mainly in I904-I907, and the map in dispute was obviously used to indicate their location and limits. ${ }^{\text {IO9 }}$ Naturally, the precise question of the ownership of the Temple of Preah Vihear was not an original issue. Raising this question involving the territorial sovereignty of an area of the size covered by the ruins of this sanctuary along with Thailand's principal claim for the retrocession of several provinces would obviously have appeared incongruous and out of place at the time. ${ }^{\text {I }}{ }^{\circ}$

\section{Judge Moreno Quintana}

Judge Quintana dissented, saying that to take a decision “on the basis of assumptions or hypotheses in order to resolve the question at issue would not seem very consistent with the rules of judicial settlement. There has been no conclusive evidence showing any tacit recognition by Thailand of the alleged Cambodian sovereignty over the area in question. It is the facts, clear facts, which must be taken into account." ${ }^{\text {II I }}$ More importantly, "watershed is not an intellectual abstraction", he noted. ${ }^{\text {II } 2}$ He cautioned that "territorial sovereignty is not a matter to be treated lightly, especially when the legitimacy of its exercise is sought to be proved by means of an unauthenticated map". ${ }^{\text {II3 }}$

Next, Quintana defended Thailand's silence. Silence has consequences in law, he said, "only if the party concerned is under an obligation to make its voice heard in response to a given fact or situation". ${ }^{14}$ Before acquiescence is used against Thailand, Quintana thought the Court must first show that Thailand was under such an obligation. ${ }^{\text {II5 }}$

\footnotetext{
I06. Ibid., at 84 .

I07. Winichakul, supra note 57 at I I 2.

I08. Thai cartography emerged from Chinese knowledge wherein the "Chinese paid more attention to their inland waterways than to their seacoast, rarely sending scientific expeditions oceanward". Phva SALWIDHANNIDHES, "Study of Early Cartography of Thailand (Siam)" (I952) 50 Journal of the Siam Society $8 \mathrm{I}$ at 82 . Not that the Europeans were always careful or accurate. Guillaume Delisle, the French father of cartography, confused Bhutan with Tibet in an eighteenth-century map. See Karma PHUNTSHO, The History of Bhutan (Gurgaon: Random House India, 2013) at 13.

I09. Dissenting Opinion of Judge Koo, supra note 59 at 89.

I Io. Ibid.

I I I. Dissenting Opinion of Judge Moreno Quintana, in Temple of Preah Vihear case, supra note 3 at 67.

I 2. Ibid., at 68 .

II3. Ibid., at 69 .

I I4. Ibid., at 70 .

I I . "An error remains an error and cannot by repetition make good acts of later date that are based upon that error." Ibid., at $7 \mathrm{I}$.
} 
Thailand had argued that the Temple, being built upon a plateau, is difficult to access from the Cambodian side while from the Thai side it is far more easily accessible. This contention seems to be correct as it is based on a geographical fact which is clearly in favour of the exercise of territorial sovereignty by the country having easy access. Having regard to the topography of the frontier area, Quintana said, "the very suggestion that the Preah Vihear area lies within Cambodian jurisdiction is really contrary to sense". ${ }^{116}$

\section{Judge Sir Percy Spender}

Judge Spender's dissent makes observations similar to that made by Judge Koo. It is easy, Sir Percy said, to fall into the error of thinking that the Temple and its sovereignty was the principal concern of the two states in 1908-1909, and therefore, "when Thailand received the maps, almost the first thing which she might be expected to do would be to see whether sovereignty over the Temple had been accorded to her. All this, I think, bears little relation to the realities." ${ }^{\text {I } 7}$ Judge Spender noted: "If these unsupportable assertions were deemed correct the two States in 1908-1909 could not have conducted themselves in a more casual and inconsequential manner in matters affecting territorial sovereignty." ${ }^{18}$ Between the three dissenters, Quintana and Spender based their opposition to the majority decision on doctrinal grounds, while Koo took a post-colonial, even an historical, approach.

\section{Siamese Political Space: The Mandala System}

"What appears to be reasonable on the map may not necessarily be reasonable from the viewpoint of implementation on the ground", Judge Owada said in 20II. ${ }^{\text {II }}$ In much of pre-colonial Asia, sovereign boundaries had been the domain of the peripheral polity. It was this aspect that the ICJ clearly denied when rejecting Thailand's argument of the provincial administration of the region in which the Temple was situated. The idea of a boundary for Siam did not mean a thin line on the territory but a zone or area under the administration of the local and provincial rulers-a political space where sovereignty was shared, as opposed to a mathematically defined territory on a piece of paper called a map. Maps, therefore, had different meanings for Siam and for the Europeans; for the former it was a spatial representation of a non-bounded kingdom, for the latter, however, a map was a representation of a controlled territory inked on a paper with mathematical precision.

In direct contrast, a mandala system of governance was central to the lives of the Asian polities from India to Indochina. ${ }^{\text {I2O }}$ Historian Thapar defines mandala theory as "a circle of kings, the one desirous of supremacy is surrounded by serried ranks of friends and enemies, and politics is connected with degrees of support and hostility within the

\footnotetext{
I 6. Ibid.

I I7. Dissenting Opinion of Judge Spender, in Temple of Preah Vihear case, supra note 3 at I37.

I 8 . I $\mathrm{bid}$.

I 19. Dissenting Opinion of President Owada, in Request for Interpretation, at 56I, para. I 5, online: < http:// www.icj-cij.org/files/case-related/I 5 I/I 5 I-20 I I07 I 8-ORD-OI-OI-EN.pdf $>$.

I 20. Kautilya ( $400 \mathrm{BC})$ is credited with the theoretical exposition of the "the Circle of States" mandala theory. L.N. RANGARAJAN, ed., Kautilya: The Arthasastra (New Delhi: Penguin, I992) 95.
} 
widening circle". ${ }^{\mathrm{I2I}}$ As a result, the sovereignty of a state in the pre-modern Asian polity was neither single nor exclusive. It was multiple and capable of being shared.

In Siam, the idea of extending a Chakravartin rule exemplified a "self-presumed protector who sought the protected to fulfill his own desire". ${ }^{22}$ Notably, however, the Asian overlord did not usurp the sovereignty of weaker tributary states, nor was it encroached upon as in modern colonialism. ${ }^{\mathrm{I} 23}$ It is no wonder that, while rooting for the validity of acts performed "by local or provincial authorities" over that of central Siamese authority, Judge Koo argued for the recognition for the mandala system, although without naming it. ${ }^{\text {I24 }}$ Judge Koo noted:

Thailand, on her part, has filed with the Court a number of affidavits and copies of original documents as evidence of acts of administrative control by Siamese authorities in exercise of sovereignty in the area in which the Temple of Preah Vihear is situated. These acts relate, among other matters, to the building of roads to the foot of Mount Preah Vihear, the collection of taxes by Siamese revenue officers on the rice fields of Mount Preah Vihear, the grant of permits to cut timber in the area, the visits and inspections by Siamese forestry officers, the taking of an officia I inventory in I93 I of ancient monuments which included the Temple of Preah Vihear. ${ }^{\text {I25 }}$

Disputes after decolonization in Asia occasioned the clash of the two models, as in the Temple of Preah Vihear case, but more recently in the Malaysia/Singapore case, involving two Asian states, again. ${ }^{\mathrm{I} 26}$ In any case, Winichakul has long argued that " $[t]$ he grid of modern mind renders the unfamiliarity of the indigenous polity and geography more familiar to us by translating them into modern discourses. Such scholars fail to recognize the rapidly increasing role of new technology of space. Consequently, these studies mislead us into considering only the point of view of those states which become modern nations." 27 That said, the Siamese rulers "borrowed the Torrens system from Australia and other countries of the British commonwealth". ${ }^{\text {228 }}$ Naturally, Siam too went on to construct a Westphalian state. After all, Asian states

I2I. Romila THAPAR, The Penguin History of Early India: From the Origins to AD I300 (New Delhi: Penguin, 2002) 446.

I22. Winichakul, supra note 107 at 84 .

I23. Ibid., at 88 .

I24. Dissenting Opinion of Judge Koo, supra note 59 at 93, para. 39.

I 25. Ibid., at 92, para. 38. Thus, much of the mandala system existed on monetary sovereignty, i.e. tax and revenue collection, rather than exclusive and homogenous control over geographical territory. "[T]he relevance and importance of territorial versus monetary sovereignty has shifted in favor of the latter." Katharina PISTOR, "From Territorial to Monetary Sovereignty" (20I7) I 8 Theoretical Inquiries in Law 49 I.

I26. Instructively enough, Ian Brownlie and Alain Pellet-two of the most doctrinal of European scholarsunsuccessfully made a case for a mandala people-centric "Malay concept of sovereignty" on behalf of Singapore. They argued that the Malay concept of sovereignty "is based mainly on control over people, and not control over territory. Traditional Malay sovereignty is people-centric and not territory-centric." In any case, the ICJ tried to balance the clash of concepts by noting "that sovereignty comprises both elements, personal and territorial”. Sovereignty over Pedra Branca/Pulau Batu Puteh, Middle Rocks and South Ledge (Malaysia/Singapore), Judgment, [2008] I.C.J. Rep I 2 at 40, paras. 76-9.

I27. "The fate of tiny tributaries under dispute remains virtually unknown. Their voices have not been heard. It is as if they occupied a dead space with no life, no view, no voice, and thus no history of their own." Winichakul, supra note 107 at 96.

I 28. Vandergeest and Lee Peluso, supra note I 5 at 4I 5 . 
were permitted to enter the province of international law only after ossifying their histories in favour of uncritical universalism.

\section{JUSTICE OVER PEACE AND THIRD-WORLD JURISTS}

Given the colonial origins of the law of territory, Sookyeon Huh says, it could not be sustained intact today since colonization as a practice has been rejected, leading to the "instability of the law of territory". ${ }^{29}$ After the ICJ ruling in the Right of Passage case, India incorporated Goa-formerly under Portuguese colonial rule-into the Union of India, offering a rethinking of the law of territory in the post-colony. ${ }^{13^{\circ}} \mathrm{At}$ the time, Judge Hidayatullah ruled that the UN Charter does not prioritize "peace over justice" in the post-colony in relation to territory. Judge Hidayatullah wrote:

The question, when does title to the new territory begin, is not easy to answer. Some would make title depend upon recognition ... when Italy conquered Abyssinia, the conquest was recognized because it was thought that the state of affairs had come to stay. Thus, although the United Nations Charter includes the obligation that force would not be used against the territorial integrity of other States (Article 2 para 4), events after the Second World War have shown that transfer of title to territory by conquest is still recognized. Prof. R.Y. Jennings poses the question: "What is the legal position where a conqueror having no title by conquest is nevertheless in full possession of the territorial power, and not apparently to be ousted?" $\mathrm{He}$ recommends the recognition of this fact between the two States. If cession after defeat can create title, occupation combined with absence of opposition must lead to the same kind of title. ${ }^{\mathrm{I}}{ }^{\mathrm{I}}$

Likewise, Gathii's epithet “Geographical Hegelianism” highlights the ICJ's problematic approach in African territorial disputes. ${ }^{132}$ Anyhow, it would be erroneous to view the Temple of Preah Vihear litigation in isolation. Equally inaccurate would be treating in isolation the views of Asian jurists such as Koo, Hidayatullah, and Guha Roy in favour of justice over peace, local customary law and arguments for the validity of oriental customs over treaty-fication of colonial stationery like maps.

Asian jurists appear all too ambivalent towards international law's sources as a result. The approach of the Republican Chinese and Indian scholars contrasted because of their differing colonial and semi-colonial experiences. For instance,

I29. Huh, supra note I9 at 7IO-II.

I30. Prabhakar SINGH, "India Before and After the Right of Passage Case" (2015) 5 Asian Journal of International Law I76.

I3 I. Likewise, Krishna Rao had detected the seeds of new imperialism insofar as, for China, the settlement of the boundary with India became a "ripe" question "for solution in 1959", and not soon after its independence in 1949, "only because China felt that she had an overwhelming strength and could enforce her 'claim' by resort to an armed intervention”. Krishna Rao, supra note 47 at 368.

132. Gathii traces the ICJ's determination of title to disputed islands that "are based on the Eurocentric assumption that only the consent of European states is necessary to adjudicate nineteenth century claims of title to territory to the exclusion of the consent of non-European peoples". Pre-existing title to territory based on African use and occupation does not count. Gathii, supra note 26 at 58 I. Cf. "That uti possidetis governs colonial situations is evident, that it extends to all cases of transition to independence has, it is believed, become clear." Malcolm SHAW, "Peoples, Territorialism and Boundaries" (I997) 8 European Journal of International Law 478 at 503. Robert MACCORCUDALE and Raul PANGALANGAN, "Pushing Back the Limitations of Territorial Boundaries" (200I) I 2 European Journal of International Law 867 at 882 : "an untangling of territorial boundaries and sovereignty is desirable." 
Hidayatullah and Koo did not share similar views on sources of international law. Koo rooted for the rejection of colonial treaties-rebus sic stantibus-on at least three occasions: during East Asian semi-colonialism, in the Right of Passage case, and in the Temple of Preah Vihear case after decolonization.

In 20 I I, Cambodia approached the ICJ for a re-interpretation of the original ruling of I962. Consequently, the ICJ issued an order indicating provisional measures where no less than five judges dissented. ${ }^{\mathrm{I} 33}$ Judge Xue Hanqin expressed "serious reservations" with the ICJ's defining of a provisional demilitarized zone as "unprecedented in the sense that the Court has never before indicated provisional measures ordering the Parties to withdraw troops or personnel from their undisputed territories”. Such a measure, in Judge Xue's view, "puts into question the proper exercise of the judicial discretion of the Court in indicating provisional measures, both under the law and by the jurisprudence of the Court". ${ }^{\text {I34 }}$ The Republican Chinese Judge Koo had in the Right of Passage case found a "military" right of passage in favour of the Portuguese, a colonial power, as a "local custom". By contrast, in her dissent on the provisional measure about the removal of the army supporting Thailand, Communist China's Judge Xue, by analogy, seems to resist the visible footprints of French imperialism.

Judge Cançado Trindade drafted his question in terms of people and populations: "What further information can be provided by the Parties to the Court about such displaced local inhabitants? How many inhabitants were displaced? Have they safely and voluntarily returned to their homes?" ${ }^{35}$ People-centricity and territoriality face each other in the Reinterpretaion of Preah Vihear case. Doubtless, when used by powerful states, the argument of "justice over peace" has a great destabilizing potential for world peace.

\section{CONCLUSION}

How do international law's leading textbooks record the Temple and Cheek cases? While the Temple of Preah Vihear case is known as a "leading case on estoppel", ${ }^{136}$ the Cheek $v$. Siam arbitration is a precedent for contractual damages involving sovereigns. Another textbook on international dispute settlement notes that the Temple of Preah Vihear case is an example that "a state may be a most unwilling litigant and yet still carry out a decision". ${ }^{37}$ Effectively, the textbook approach to the Temple of Preah Vihear case encrypts Asian legal histories. ${ }^{{ }^{13} 8}$

133. Request for Interpretation of the Judgment of I June 1962 in the Case Concerning the Temple of Preah Vihear (Cambodia $v$. Thailand), Provisional Measures, Provision Order [20I I] I.C.J. Rep 537. President Owada, Judges Al-Khasawneh, Xue, Donoghue, and Judge ad hoc Cot all dissented.

I34. Dissenting Opinion of Judge Xue, Provisional Measure, ibid., at 608.

I35. Reply of the Kingdom of Thailand to the question put to the Parties by Judge Cançado Trindade ( 7 June 2OII), online: < http://www.icj-cij.org/files/case-related/I 5 I/I 7656 .pdf > .

I36. Malcolm SHAW, International Law, 6th ed. (Cambridge: Cambridge University Press, 2008) 5I8; Robert KOLB, Theory of International Law (Portland, OR: Hart Publishing, 20I6) 40I. James CRAWFORD, Brownlie's Principles of Public International law, 8th ed. (Oxford: Oxford University Press, 2012) 420-1.

I37. John MERRILLS, International Dispute Settlement (Cambridge: Cambridge University Press, 20 I I) I 60.

I38. Referring to Judge Fitzmaurice's Separate Opinion in the Temple of Preah Vihear case, Akehurst's textbook notes: "[s]ometimes international law insists on the English requirements of reliance and detriment." Peter MALANCZUK, Akehurst's Modern Introduction to International law, 7th ed. (London/ New York: Routledge, I997) I 54. 
Moreover, the Preah Vihear litigation confirms that political post-colonialism and epistemological decolonization, if any, are not time twins. Participation in international litigation in relation to territorial questions becomes a proxy for converting a semi-colonial Asian past into European, thus universal, history. Semi-colonial Siam's assumed historical scarcity, as it were, offers Siam merely a past. In contrast, historical surpluses produced by colonial stationery gives Cambodia a history that is aligned with international law's universalization. It is as if international law seeks its universalization by laundering Asian unauthentic past for a universal history through international lawyers as interlocutors.

One would assume that dissimilar escapades-i.e. semi-colonialism, colonial rule, or any other model in between-in Asia or elsewhere must necessarily lead to plural postcolonialisms. Today while ex-colonial India accepts the legality of colonial treaties, China rejects both colonial and post-colonial treaties in favour of customs; Thailand takes a ground somewhere in between India and China. Yet, as the Temple of Preah Vihear case explains, the ICJ as the "principle judicial organ" for international law's universalism paints all histories with a broad European brush. Theoretically speaking, the Preab Vihear dispute is a case of the deployment of Thailand's assumed semi-colonial scarcity against effusive surpluses from French colonialism in Indochina.

Within positive international law, the production of colonial stationery such as photographs and cartography translate into the creation of a relative scarcity of evidence at international courts for territorial claims in erstwhile semi-colonial polities. In effect, Cambodia's mimicking of colonial opportunism by using French colonial stationery represents an abdication of Siamese conceptions of space in favour of a colonial conception of territory. The artificial scarcity of colonial stationery in semi-colonies resulted in Thailand losing is claim over the Temple and surrounding territory. Nevertheless, having realized the value of maps as evidence, rising Asian powers display a cartographic aggression to sustain newly acquired imperial ambitions. ${ }^{\text {I39 }}$ Even so, international law appears to be conclusively biased in favour of erstwhile colonial polities, while disadvantaging semi-colonial nations like Siam that managed to remain independent.

I39. Sucharitkul placed Judge Koo's dissent in the Temple of Preah Vihear case in perspective: “Judge Koo's dissenting opinion in regard to the need for Siam to react against France's aggression on paper by publication of a map with inaccurate boundary line showing the Temple of Phra Vihear to be outside Siam." Sucharitkul, supra note 47 , at 9. 
Table I. International law during the Bangkok period (I82I-I962).

\begin{tabular}{|c|c|c|}
\hline Year & Item & Feature \\
\hline I $82 \mathrm{I}$ & Crawfurd Mission & $\begin{array}{l}\text { - Re-crowning the Sultan of Kedah } \\
\text { - Negotiating a free-trade treaty between the East India } \\
\text { Company and Siam } \\
\text { - Securing Burmese border with Siam }\end{array}$ \\
\hline I 826 & Burney Treaty & - Burma-Siam boundary treaty \\
\hline I 855 & Bowring Treaty ${ }^{\mathrm{I} 4 \mathrm{O}}$ & $\begin{array}{l}\text { - The Bowring Treaty a model for other imperialist states } \\
\text { - Opened up internal markets by making most monopolies } \\
\text { illegal } \\
\text { - Siam restricted in: } \\
\text { - (I) the ability of the state to tax land, (2) the right of the } \\
\text { state to decide who could own land where, and } \\
\text { - (3) extra-territoriality }\end{array}$ \\
\hline I 856 & Parkes Agreement & $\begin{array}{l}\text { - Recodification of financial system } \\
\text { - Specification of taxes the Siamese government could levy on } \\
\text { land }\end{array}$ \\
\hline I 856 & $\begin{array}{l}\text { Franco-Siamese Treaty of } \\
\text { Friendship, Commerce, } \\
\text { and Navigation }{ }^{\mathrm{I} \mathrm{I}^{\mathrm{I}}}\end{array}$ & $\begin{array}{l}\text { - Article I: calls for "constant peace and perpetual } \\
\text { friendship" } \\
\text { - Article I: Siamese vessel to receive the protection of French } \\
\text { warships } \\
\text { - Article 5: Bangkok to be the only permanent residence for } \\
\text { French nationals } \\
\text { - Article I } 5 \text { : French warships may enter rivers, to notify } \\
\text { beforehand if "ascending to Bangkok" } \\
\text { - Article I } 8 \text { : Import duty on goods from French Vessel to } \\
\text { Siam shall exceed no more than } 3 \% \text { of the value }\end{array}$ \\
\hline I 867 & Franco-Siamese Treaty ${ }^{\mathrm{I} 42}$ & $\begin{array}{l}\text { - Article I: Siam recognizes French protectorate over } \\
\text { Cambodia } \\
\text { - The Siam-Cambodia Treaty of Oudong, I } 863 \text {, declared } \\
\text { "null and void" }\end{array}$ \\
\hline I 887 & $\begin{array}{l}\text { Japan-Siam diplomatic ties } \\
\text { begin }\end{array}$ & - Declaration of Amity and Commerce \\
\hline I893 & $\begin{array}{l}\text { Franco-Siamese Treaty and } \\
\text { Convention }^{\mathrm{I} 43}\end{array}$ & $\begin{array}{l}\text { - Chao Phaya River blockade by France } \\
\text { - Article I: Siam renounces claims to all territories on the left } \\
\text { bank of the Mekong } \\
\text { - Article 3: Siam will not construct military forts etc. in } \\
\text { Battambang and Siemreap }\end{array}$ \\
\hline
\end{tabular}

I40. Treaty of Friendship and Commerce between Siam and Great Britain Signed at Bangkok, I 8 April I 855 , Empire in Asia: A New Global History, online: National University of Singapore < http://www.fas.nus. edu.sg/hist/eia/documents_archive/friendship-treaty.php $>$.

I4I. Tuck, supra note 71 at Appendix 2, 263-73.

I42. Ibid., at 287-9.

I43. Ibid., at $29 \mathrm{I}-5$. 
Table I. (Continued)

\begin{tabular}{|c|c|c|}
\hline Year & Item & Feature \\
\hline I 894 & Phra Yot dispute & $\begin{array}{l}\text { - Siam proposes the creation of a "Mixed International } \\
\text { Court" which France rejects } \\
\text { - Special Court exonerates Phra Yot with a verdict of I7 } \\
\text { March I } 894 \\
\text { - A second, Franco-Siamese Mixed Court set up with two } \\
\text { French judges, two Siamese judges and a French President } \\
\text { - On I3 June I } 894 \text { Phra Yot was found guilty and sentenced } \\
\text { to death } \\
\text { - After British intervention, France agreed to let Phra Yot } \\
\text { serve his sentence in a Siamese prison }\end{array}$ \\
\hline I 896 & $\begin{array}{l}\text { Anglo-French } \\
\text { Declaration }^{\mathrm{I} 44}\end{array}$ & $\begin{array}{l}\text { - Neither England nor France shall advance their armed } \\
\text { forces } \\
\text { - Not acquire any special privilege or advantage within } \\
\text { Menam Valley }\end{array}$ \\
\hline I 897 & $\begin{array}{l}\text { Anglo-Siamese Secret } \\
\text { Convention }{ }^{\mathrm{T} 45}\end{array}$ & $\begin{array}{l}\text { - Precaution to preserve the secrecy of the Convention } \\
\text { - The Straits Settlements government in Singapore not } \\
\text { informed } \\
\text { - Britain to help Siam in case of imperial aggression }\end{array}$ \\
\hline I 898 & Cheek v. Siam Award & $\begin{array}{l}\text { - Indemnity to be paid by the Siamese government } \\
\text { - No consideration in the contract that Dr Cheek breached }\end{array}$ \\
\hline I 898 & Japan-Siam Treaty & $\begin{array}{l}\text { - First treaty between Japan and Siam } \\
\text { - Japan gets extra-territorial (consular) jurisdiction in Siam }\end{array}$ \\
\hline I90I & $\begin{array}{l}\text { Torrens system and } \\
\text { cadastral mapping } \\
\text { introduced in Siam }\end{array}$ & $\begin{array}{l}\text { - Internal territorial consolidation }{ }^{\mathrm{I} 46} \\
\text { - The I90 I Land Code made state-guaranteed land rights } \\
\text { contingent on a cadastral survey and registration. }{ }^{\mathrm{I} 47}\end{array}$ \\
\hline 1902 & $\begin{array}{l}\text { The Siamese-Kelantan } \\
\text { Treaty }^{\text {I48 }}\end{array}$ & - Settlement of southern border (with British Malaya) \\
\hline 1904 & $\begin{array}{l}\text { Franco-Siamese } \\
\quad \text { Convention }^{\mathrm{I} 49}\end{array}$ & $\begin{array}{l}\text { - Demarcation of the Siam-Cambodia frontier } \\
\text { - Article I: Mekong remains the frontier of Siam } \\
\text { - Article 4: Siam gives up Luang Prabang } \\
\text { - Article 6: Siamese military to only have Siamese nationals; } \\
\text { police could have foreign nationals }\end{array}$ \\
\hline 1904 & $\begin{array}{c}\text { Entente cordiale between } \\
\text { Britain and France }{ }^{150}\end{array}$ & $\begin{array}{l}\text { - The "Siam clause" on non-intervention and buffer creation } \\
\text { - France and Britain to act only in their spheres of influence }\end{array}$ \\
\hline
\end{tabular}

I44. Ibid., at 297 .

I45. N. THAMSOOK, "The Angle-Siamese Secret Convention of I897" (I965) 53 Journal of the Siam Society 45 at $5 \mathrm{I}-2$.

I46. Vandergeest and Lee Peluso, supra note 15 at 403.

I47. Ibid.

I48. K. SUWANNATHAT-PIAN, “The I902 Siamese-Kelantan Treaty: An End to Traditional Relations" (1984) 72 Journal of the Siam Society 95 at 136 , Appendix B.

I49. Tuck, supra note I 40 at 305 .

I 50 . Ibid., at 3 I 5 . 
Table I. (Continued)

\begin{tabular}{|c|c|c|}
\hline Year & Item & Feature \\
\hline 1907 & Franco-Siamese Treaty ${ }^{15 \mathrm{I}}$ & $\begin{array}{l}\text { - Settlement of Siam-Indochina frontiers } \\
\text { - Article I: Siam ceded to France Battambang, Siemreap, and } \\
\text { Sisophan } \\
\text { - Article 2: France cedes Dan-Sai and Kratt } \\
\text { - Mixed commission to demarcate "new frontiers" after } \\
\text { ratification }\end{array}$ \\
\hline 1908 & $\begin{array}{l}\text { Modern Law codes } \\
\text { promulgated }\end{array}$ & $\begin{array}{l}\text { - Japanese jurist Tokichi Masao involved in the Siamese law- } \\
\text { drafting }\end{array}$ \\
\hline 1909 & Anglo Siamese Treaty ${ }^{152}$ & $\begin{array}{l}\text { - Secret convention of } \mathrm{I} 897 \text { abrogated } \\
\text { - Siam gives its } 4 \text { southern Malay provinces to Britain }{ }^{\mathrm{I} 53}\end{array}$ \\
\hline I9I7 & $\begin{array}{l}\text { Prince Damrong } \\
\text { Rajanubhab's } \\
\text { contribution }\end{array}$ & $\begin{array}{l}\text { - Thai Rop Phama authored } \\
\text { - First attempt at analytical history based on documentary } \\
\text { evidence }\end{array}$ \\
\hline 1933 & On Japanese aggression & - Siam abstains from voting against Japan \\
\hline 1935 & On Italian aggression & - Siam votes against Italian invasion of Ethiopia \\
\hline $\begin{array}{c}1927^{-} \\
29\end{array}$ & $\begin{array}{l}\text { Siam-Japan Treaty of } \\
\text { Friendship and } \\
\text { Commerce }\end{array}$ & - Japan abolishes extra-territoriality in Siam \\
\hline 1939 & Name change & - Siam renamed Thailand \\
\hline I94I & The Pacific War & - Siam signs pact of alliance with Japan \\
\hline 1946 & UN admission & - Admission of Siam to the United Nations \\
\hline 1962 & Preah Vihear dispute & $\begin{array}{l}\text { - Annex Map attached to the Treaty established that the } \\
\text { Temple belonged to Cambodia } \\
\text { - Silence is preclusive; map is part of the treaty } \\
\text { - A textbook approach adopted }\end{array}$ \\
\hline
\end{tabular}

I 5 I. Ibid., at 321-3.

I 52. Thamsook, supra note I 44 at 60.

I 53. Winichakul, supra note 57 at 94 . 